Boletín de la Sociedad Geológica Mexicana

VOLUMEN 61, NÚM 1, 2009, P. 47-56

\title{
Natural $v s$. anthropogenic sources of hydrocarbons as revealed through biomarker analysis: A case study in the southern Gulf of Mexico
}

\author{
Barbara M. Scholz-Böttcher ${ }^{1, *}$, Stefanie Ahlf ${ }^{1}$, Felipe Vázquez-Gutiérrez², Jürgen Rullkötter ${ }^{1}$ \\ ${ }^{1}$ Institute of Chemistry and Biology of the Marine Environment (ICBM), Carl von Ossietzky University of Oldenburg, P. O. Box 2503, D-26111 \\ Oldenburg, Germany. \\ ${ }^{2}$ Laboratorio de Fisicoquímica Marina, Instituto de Ciencias del Mar y Limnología, Universidad Nacional Autónoma de México, 04510 México, \\ D.F., México. \\ *Email: bsb@icbm.de
}

\begin{abstract}
Biological markers are organic compounds in geological samples with an unambiguous link to specific precursor molecules in living organisms. They provide information on the origin and depositional environment of fossil organic matter as well as about its thermal maturation caused by geothermal heat flow during burial. Petroleum and its refinery products carry this biomarker information into the environment when they are released during anthropogenically-induced pollution. Soils or aquatic surface sediments in contaminated areas usually contain binary mixtures of fossil hydrocarbons and recent biogenic hydrocarbons like higher-plant wax esters, together with (often olefinic) hydrocarbons from earliest diagenetic transformation of functionalized biomolecules. Surface sediments collected in the shelf area of the Campeche Sound, Gulf of Mexico, sampled in the course of environmental monitoring for possible petroleum pollution due to industrial activity, however, revealed a third group of hydrocarbons. GC-MS analysis of biomarkers in the nonaromatic hydrocarbon fractions of the sediment extracts yielded overlapping hydrocarbon assemblages indicating multiple sources. Samples taken close to known asphalt seeps exhibit biomarker patterns virtually identical to those of reference crude oils. Other sediments contain mature fossil hydrocarbons and biomarkers that are not typical of either fossil fuels or immature organic matter in marine surface sediments. Instead, they come from drill cuttings recovered during penetration of Tertiary to Cretaceous deposits that were littered on the shallow sea bottom.
\end{abstract}

Keywords: n-alkane, biomarker, Campeche Sound, diploptene, Gulf of Mexico, hopanes, oleanene, petroleum, pollution, steranes, surface sediments

\section{Resumen}

Los biomarcadores son compuestos orgánicos que están presentes en muestras geológicas y tienen una relación inequívoca con precursores moleculares específicos de organismos vivos. Proporcionan información acerca del origen y el ambiente deposicional de la materia orgánica fósil así como de la maduración térmica causada por el flujo de calor geotérmico durante su soterramiento. El petróleo y sus productos de refinado, cuando se incorporan al medio ambiente por procesos de polución antropogénica, transfieren a éste la información acumulada en sus biomarcadores. Los suelos o los sedimentos acuáticos superficiales en áreas contaminadas usualmente contienen mezclas binarias de hidrocarburos fósiles y biogénicos, como son los ésteres céricos de plantas superiores, junto con hidrocarburos (a menudo olefínicos) provenientes de las transformaciones diagenéticas tempranas de moléculas funcionarizadas. En este contexto, durante un estudio de vigilancia ambiental por posible contaminación petrolígena debida a la actividad industrial, se observó un tercer grupo de hidrocarburos en los sedimentos superficiales recogidos en la costa continental de la Sonda de Campeche, al sur del Golfo de México. El análisis por GC-MS de estos biomarcadores separados en fracciones de hidrocarburos no aromáticos de extractos de sedimentos mostró la presencia de mezclas de hidrocarburos que se solapaban, indicando fuentes múltiples. Las muestras recogidas cerca de filtraciones asfálticas naturales conocidas tenían distribuciones de biomarcadores que eran virtualmente idénticas a las de petróleos de referencia. Otros sedimentos contenían hidrocarburos fósiles maduros y biomarcadores típicos que no son característicos de combustibles fósiles ni de materia orgánica inmadura en sedimentos marinos superficiales. Se concluyó que dichos hidrocarburos provenían de perforaciones realizadas en depósitos del Cretácico al Terciario durante las que se descargaron los residuos sedimentarios al fondo marino somero.

Palabras clave: n-alcanos, biomarcadores, Sonda de Campeche, diplopteno, Golfo de México, hopanos, oleanano, petróleo, polución, esteranos, sedimentos superficiales 


\section{Introduction}

Biological markers (biomarkers) or molecular/chemical fossils are organic compounds in natural waters, sediments, soils, fossils, crude oils, or coal that can be unambiguously linked to specific precursor molecules biosynthesized by living organisms (e.g., Rullkötter, 2001, 2006; Peters et al., 2005; Gaines et al., 2008; and references therein for recent overviews). The initial biological marker concept - particularly when its early application to petroleum geochemistry started some forty years ago - was based on the idea that geochemical transformation of structurally significant biomolecules during diagenesis and catagenesis produces, among others, saturated hydrocarbons with carbon skeletons identical to those of the precursor molecules.

This simple fingerprint concept developed into a considerably more sophisticated organic geochemical tool when it became apparent in the 1980s and beyond that during catagenesis subtle changes occur in the sterical configuration of the saturated biomarker hydrocarbons (e.g., Mackenzie et al., 1980, 1981; Seifert and Moldowan, 1980; Seifert et al., 1980; Peters et al., 2005). This conversion, termed thermal maturation and closely connected to the formation of petroleum by thermal cracking of kerogen in hydrocarbon source rocks, lead from a single precursor stereochemistry to a pair or a handful of epimers in which the sterical orientation at one or more carbon atoms is altered, usually in a way that the product is thermodynamically more stable than the precursor. From these transformation reactions molecular were developed maturity parameters which express the extent of geothermal heating that has affected sedimentary organic matter. As a consequence, the distributions of fossil biomarkers in geological samples have to be interpreted in terms of both source characteristics (the old fingerprint approach) and maturity signals (the transformation concept). For the former, the carbon number distribution of steranes $\left(\mathrm{C}_{27}\right.$ to $\mathrm{C}_{29}$ or $\left.\mathrm{C}_{30}\right)$ is a typical example, whereas sterane epimer ratios adhere to the latter (e.g., Peters et al., 2005; Gaines et al., 2008; and references therein). Table 1 illustrates some examples of precursor-product relationships of biomarkers relevant to the present environmental study of surface sediments from the southern Gulf of Mexico.

Several years ago the state oil company PEMEX together with the Autonomous National University of Mexico started an environmental monitoring program on the shelf and upper continental slope of the Campeche Sound to assess the extent and regional distribution of pollution by heavy metals (Vázquez and Virender, 2004) and petroleum hydrocarbons (ScholzBöttcher et al., 2008). They established a grid system of more than 100 sampling points for collecting surface sediments. In connection with the planned extension of exploration activities into the deep-water area of the Campeche Sound (Soto-Cuervo et al., 2004), in recent years surface sediment samples and seeping asphalts were also collected from the adjacent abyssal Gulf of Mexico (Figure 1).

Commonly, contamination of surface sediments in aquatic systems or soils with crude oil or its refinery products is indicated by the presence of hydrocarbons that bear the typical maturity characteristics of organic matter from deeply buried sediments (e.g. petroleum). These petroleum hydrocarbons are mixed with autochthonous and allochthonous biogenic hydrocarbons from aquatic organisms (like short-chain $n$-alkanes from algae, in low abundance) or higher land plants (like long-chain wax alkanes, commonly more abundant) and with products of the earliest diagenetic transformation of functionalized biomolecules to saturated and particularly olefinic (non-aromatic) hydrocarbons, usually involving the activity of heterotrophic bacteria.

In the surface sediments from the Campeche Sound, however, a third type of hydrocarbons was present which could neither be attributed to petroleum nor to biogenic organic material and its earliest diagenetic transformation products. In order to resolve this enigma and to elucidate the sources of the different groups of hydrocarbons, we performed the gas chromatography-mass spectrometry (GC-MS) analysis of non-aromatic hydrocarbon biomarkers extracted from representative surface sediments from the Campeche Sound and a series of reference materials.

\section{Study area and sample material}

The Cantarell complex underlying the Campeche Sound in the Southeast Gulf of Mexico (Figure 1) is the largest oil province in Mexico producing more than 3.5 million barrels of crude oil per day in several oilfields onshore and offshore (Pemex Exploración y Producción, 2006). The bottom of the shallow shelf bay, where in most parts the water depth does not exceed 40-50 meters, houses a network of pipelines used to transport most of the produced oil to the nearby coastal area. In addition to the exploration and production activities and the heavy ship traffic in the Campeche Sound, the refinery industry on land and other land run-off as well as natural asphalt seeps are potential sources of pollution of water and sediment in the offshore area with petroleum hydrocarbons (García-Cuéllar et al., 2004). Asphalts occur within the sediment (termed asphaltic samples in this study), but also as virtually pure extrusions from the subsurface, particularly in the abyssal part of the Campeche Sound ("asphalt volcanism" by MacDonald et al., 2004; termed asphalt samples in this study). In the surface sediments of the Campeche Sound, drill cuttings discarded into the sea for an extended number of years during exploration and production drilling are another potential source of hydrocarbon contamination.

For this study, we investigated 83 surface sediment samples from the 2006 environmental sampling campaign. Asphalt samples, several crude oils, and drill cuttings samples from four different production wells stored in the PEMEX core repository were used as reference materials. The sampling locations of selected representative surface sediments discussed in the text are shown in Figure 1.

\section{Analytical methods}

Surface sediments from box cores were freeze-dried, 


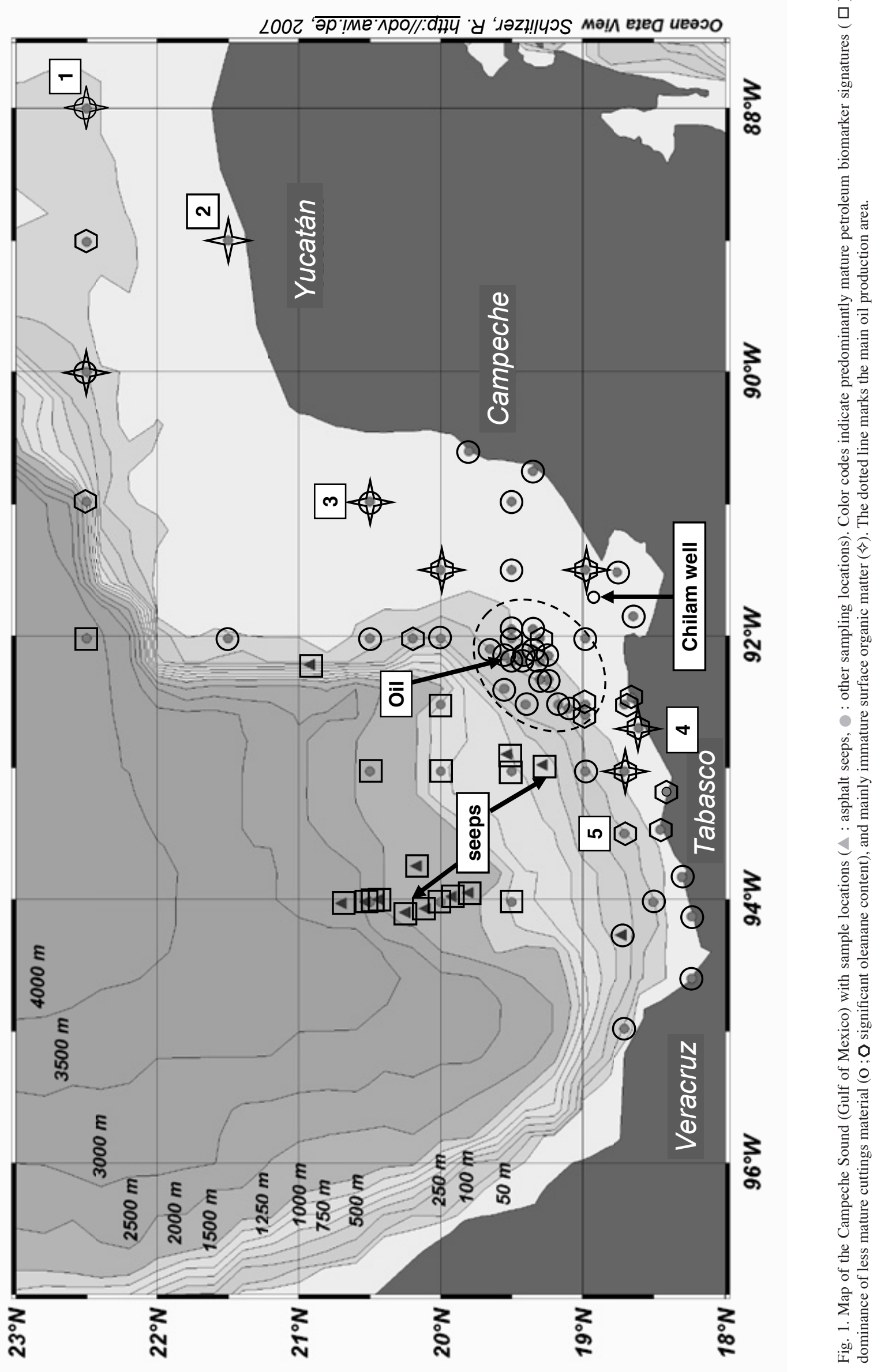


Table 1. Source-product relationships of selected biomarkers and their geochemical significance (cf, Gaines et al., 2008).

\begin{tabular}{|c|c|c|}
\hline Biological molecule & Structure (example) & Known or postulated source \\
\hline \multicolumn{3}{|l|}{ Straight chains } \\
\hline $\begin{array}{c}1 \text { n-Alkane (odd carbon number) } \\
\mathrm{C}_{25}-\mathrm{C}_{35} \\
\mathrm{C}_{15}-\mathrm{C}_{19}\end{array}$ & & $\begin{array}{l}\text { Higher land plant leaf waxes } \\
\text { Marine phytoplankton }\end{array}$ \\
\hline \multicolumn{3}{|l|}{ Pentacyclic triterpenoids } \\
\hline $\begin{array}{l}16 \text { Bacteriohopanetetrol and } \\
\text { related hopanoids }\end{array}$ & & $\begin{array}{l}\text { Bacteria (mostly aerobic, } \\
\text { heterotrophic) }\end{array}$ \\
\hline $\begin{array}{l}19 \text { Diploptene } \\
\text { Diplopterol }\end{array}$ & & $\begin{array}{l}\text { Aerobic bacteria } \\
\text { (Methanotrophic bacteria if }{ }^{13} \mathrm{C} \text { - } \\
\text { depleted) }\end{array}$ \\
\hline $20 \beta$-Amyrin & & Flowering plants \\
\hline \multicolumn{3}{|l|}{ Steroids } \\
\hline 23 Cholesterol & & Eucaryotes \\
\hline Coprostanol & & Mammalian feces \\
\hline $\begin{array}{l}24 \text { 24-Methylcholesterol and } \\
\text { double bond homologues }\end{array}$ & & $\begin{array}{l}\text { Mainly diatoms, red lineage of } \\
\text { algae }\end{array}$ \\
\hline $\begin{array}{l}25 \text { 24-Ethylcholesterol and } \\
\text { double bond homologues }\end{array}$ & & $\begin{array}{l}\text { Mainly green algae \& higher land } \\
\text { plants }\end{array}$ \\
\hline
\end{tabular}

ground and extracted with dichloromethane by ultrasonication. Pure asphalts were directly dissolved in dichloromethane and the solution filtered. Fractions of non-aromatic (i.e. saturated plus olefinic) hydrocarbons were obtained by medium pressure liquid chromatography (Radke et al., 1980). They were injected in splitless mode into a Hewlett Packard 5890 Series 2 gas chromatograph equipped with a cold injection system (KAS 3 , Gerstel) and a 60-m HP-1MS fused-silica capillary column of $0.25 \mathrm{~mm}$ i.d. and $0.25 \mu \mathrm{m}$ film thickness. The cold injector was heated from $55^{\circ} \mathrm{C}(0.08 \mathrm{~min})$ at a rate of $8^{\circ} \mathrm{C} / \mathrm{s}$ to $320^{\circ} \mathrm{C}(2$ $\mathrm{min})$, and the $\mathrm{GC}$ oven was heated from $60^{\circ} \mathrm{C}(2 \mathrm{~min})$ at $15^{\circ} \mathrm{C} /$ min to $150^{\circ} \mathrm{C}$, then at $2^{\circ} \mathrm{C} / \mathrm{min}$ to $310^{\circ} \mathrm{C}(60 \mathrm{~min})$. Helium was used as carrier gas. The GC was coupled to a Finnigan MAT
95Q mass spectrometer operated at an ionization energy of $70 \mathrm{eV}$ and at a scan cycle time of $1.2 \mathrm{~s}$ either in the multiple ion detection or full scan mode. For biomarker interpretation the mass fragmentograms of $\mathrm{m} / \mathrm{z} 191$ (triterpenoids), 217+218 (steranes), and 183 (n-alkanes) were used.

\section{Results and Discussion}

\subsection{Crude oils}

The source rocks of the oils produced in the southern central Campeche Sound area are mostly of Tithonian (Upper Jurassic) age and are partly calcareous (Angeles-Aquino, 1987, 1994; Holguín, 1987; Guzmán-Vega and Mello, 1999; Guzmán- 


\begin{tabular}{|c|c|c|}
\hline Fossil molecule & Structure (examples) & Biogeochemical application \\
\hline \multicolumn{3}{|l|}{ Straight chains } \\
\hline $\begin{array}{l}1 \text { n-Alkane } \\
\quad \text { (unaltered, } \mathrm{C}_{25}-\mathrm{C}_{35}, \text { odd) }\end{array}$ & & Land plant organic matter \\
\hline $\begin{array}{l}\text { n-Alkane } \\
\text { (shorter chains, odd \& even) }\end{array}$ & & $\begin{array}{l}\text { Mature organic matter, petroleum } \\
\text { contamination }\end{array}$ \\
\hline \multicolumn{3}{|l|}{ Pentacyclic triterpenoids } \\
\hline $\begin{array}{l}16 \text { Extended hopanes } \\
\qquad\left(\mathrm{C}_{27}, \mathrm{C}_{29}-\mathrm{C}_{35} \text {, rare: } \mathrm{C}_{35+}\right)\end{array}$ & & $\begin{array}{l}\text { Bacteria (mostly aerobic) } \\
\text { stereoisomer ratios used as } \\
\text { maturity indicator }\end{array}$ \\
\hline $1917 \alpha$-Hopane & & Aerobic (methanotrophic) bacteria \\
\hline $2018 \beta$ - and $18 \alpha$-Oleanane & & $\begin{array}{l}\text { Flowering plants } \\
\text { In oils indicates early Cretaceous } \\
\text { or younger source rock }\end{array}$ \\
\hline \multicolumn{3}{|l|}{ Steroids } \\
\hline $\begin{array}{l}23 \text { Cholestane } \\
\text { Diasterane } \\
\text { Mono- and triaromatic steroid } \\
\text { (several isomers for each type) }\end{array}$ & & $\begin{array}{l}\text { Carbon number distributions and } \\
\text { ratios }\left(\mathrm{C}_{27}, \mathrm{C}_{28}, \mathrm{C}_{29}\right) \text { : general } \\
\text { source indicator; stereoisomer } \\
\text { ratios: maturity indicators }\end{array}$ \\
\hline $\begin{array}{l}24 \text { 24-Methylcholestanes } \\
\text { (several isomers) }\end{array}$ & & As for cholestane \\
\hline $\begin{array}{l}25 \text { 24-Ethylcholestanes } \\
\text { (several isomers) }\end{array}$ & & $\begin{array}{l}\text { As for cholestane, high relative } \\
\text { abundance: land plant organic } \\
\text { matter, freshwater environment } \\
\text { or green algae }\end{array}$ \\
\hline
\end{tabular}

Vega et al., 2001). Accordingly, the terpane distributions of the crude oils, represented by their characteristic $\mathrm{m} / \mathrm{z} 191$ mass fragmentogram mainly showing mainly a pseudohomologous series of 17 $\alpha, 21 \beta$-hopanes (Figure 2a, top; $c f$. also Table 1), lack the angiosperm biomarker oleanane that commonly occurs in samples of Cretaceous and younger age (Moldowan et al., 1994; Taylor et al., 2006). In the sterane $(\mathrm{m} / z$ 217+218) patterns, diasteranes are only present in low relative abundance, consistent with a calcareous depositional environment (Figure $2 \mathrm{a}$, bottom). The $n$-alkane patterns of the oil samples reflect a typical distribution curve for fairly mature organic matter with an envelope skewed toward the homologues with shorter chain lengths (Figure $3 \mathrm{~g}$ ). There is a small preference of $n$-alkanes with even carbon-numbers which is characteristic for crude oils from calcareous source rocks (Carbon Preference Index
$(\mathrm{CPI})<1$; Figure $3 \mathrm{~g}$ ) that were released slightly before peak oil generation. The sterane epimer ratios (Table 2) also indicate that peak oil generation has not yet been reached. Both the $20 S /(20 S+20 R)$ epimer ratio $C_{29} 5 \alpha, 14, \alpha, 17 \alpha$-steranes and the $\alpha \beta \beta /(\alpha \alpha \alpha+\alpha \beta \beta)$ epimer ratio of $C_{29} 5 \alpha, 14, \beta, 17 \beta$ - and $5 \alpha, 14, \alpha, 17 \alpha$-steranes have not reached their equilibrium values of 0.53 and 0.80 , respectively (e.g., Peters et al., 2005). The relatively high hopane/moretane ratio (Table 2 ) probably indicates that the influence of terrigenous plants on the organic matter in the source rock was low (cf. Peters et al., 2005).

\subsection{Pure asphalts and asphaltic sediments}

Asphaltic sediment samples taken in the vicinities of known asphalt seeps - both in the abyssal section and on the 
continental slope - and pure asphalt samples, including those collected during cruise M67/2 of the German research vessel METEOR (MacDonald et al., 2004), unless they are severely biodegraded and the parameters cannot be measured anymore (see Peters et al., 2005, for biodegradation ranking), all exhibit source- and maturity-related biomarker patterns very similar to those of the studied reference crude oils ( $c f$. Figure 2d; Table 2). As an example, the similarity between the biomarker pattern of the asphaltic material in a surface sediment and that in a crude oil sample is illustrated by their $\mathrm{m} / \mathrm{z} 191$ traces (cf. Figures 2a, top, and 2d, top). Differences in the sterane distribution patterns are due to partial biodegradation of the asphaltic material in the surface sediment; in particular, the $\mathrm{C}_{27}$ and $\mathrm{C}_{28}$ steranes (less strongly branched in the sidechain) appear to be partly reduced in abundance relative to the $\mathrm{C}_{29}$ steranes ( $c f$. Figures 2a, bottom, and 2d, bottom) as would be expected from previous observations which led to the biodegradation ranking of Peters et al. (2005). Thus, according to the more stable polycyclic saturated hydrocarbon biomarkers (Table 2), fluids appear to have escaped from petroleum reservoirs with permeable (fractured?) cap rock in an area strongly affected by salt diapirism (Bryant et al., 1991; Macgregor, 1993). However, whether these fluids initially were conventional oils that were later biodegraded during or after migration to the surface, or were heavy oils already partly degraded in the reservoir, or even were directly released from their source rock(s), cannot be safely decided based on the data available.

The $n$-alkane distributions of pure asphalts and asphaltic sediments suggest that either the first of the three alternatives is true or that several of the processes mentioned were involved. At least one of the pure asphalts exhibits an $n$-alkane distribution pattern (Figure $3 \mathrm{~h}$ ) that shows no indications of biodegradation and closely matches that of the unbiodegraded crude oils (e.g., Figure 3g) even in its CPI value (Table 2). In contrast, the $n$-alkane distributions of the asphaltic sediments shown in Figures 3e and 3f appear to reflect biodegraded (and/ or water washed?) hydrocarbon assemblages, resulting in a kind of Gaussian distribution with a maximum around the $\mathrm{C}_{31}$ or $\mathrm{C}_{32} n$-alkane. The trimodal $n$-alkane envelope of the second seep sample (Figure 3f; first maximum not well defined possibly due to loss of volatile material during solvent removal after extraction) appears to comprise a mixture of fresh (oillike) and altered (biodegraded) hydrocarbons. Contamination of that sample with refinery products cannot be ruled out.

\subsection{Surface sediments}

As described for the asphaltic sediments, the $n$-alkanes in many of the surface sediments analyzed are mixtures from different sources. Some little contaminated coastal sediments (e.g., sample 4 in Figure 1) show long-chain $n$-alkane distributions typical of recent land plant waxes with a strong odd-over-even carbon number predominance (CPI $>>1$; Table 2; Figure 3c), indicating intense land run-off, and no geogenic $n$-alkanes. The $n$-alkane distributions in surface sediments from other sampling locations in the study grid (samples 1, 2 and 3 in Figure 1) are mixtures of low- (centered around the $\mathrm{C}_{20}$ homologue) and high-boiling $n$-alkanes (centered around the $\mathrm{C}_{29}$ homologue) with almost no carbon number preference (Figures 3a,b; Table 2, CPI values close to unity) and a Gaussian shape typical of distillation processes in refineries. Only the $n-\mathrm{C}_{27}, n-\mathrm{C}_{29}$, and $n$ - $\mathrm{C}_{31}$ alkanes are slightly more abundant pointing to a supplementary imprint of recent higher plant waxes (Figures 3a,b). Sediment sample 5 (Figure 3d) contains $n$-alkanes that appear to be almost exclusively from a refinery product (heavy diesel oil).

Most of the shelf surface sediments yield complex sterane and terpane biomarker patterns. Except for sample 4 the biomarker ratios indicate advanced thermal maturation of the organic material (Table 2). Interestingly, in most cases not only the imprint of crude oil or refinery products and very immature hydrocarbons (from recent plants, bacteria or earliest diagenesis) is clearly recognizable. In addition, the samples contain biomarkers that indicate an intermediate (marginal) maturity typical of organic matter buried to a depth of several hundreds or a few thousand meters, but not deep enough for thermocatalytic cracking of kerogen and petroleum generation. The terpane $(\mathrm{m} / \mathrm{z}$ 191) traces typical of the local crude oils (e.g., Figure 2a, top) are more or less strongly superimposed by biomarkers representing organic material of low to moderate maturity (Figures $2 \mathrm{~b}, \mathrm{c}, \mathrm{e}, \mathrm{f}$ ).

Among these components are olefins like diploptene (hop$22(29)$-ene) and hop-17(21)-enes as well as saturated $17 \beta, 21 \beta$ hopanes. Diploptene (together with diplopterol) is a common constituent of aerobic bacteria living in surface sediments ( $c f$. Table 1) and just typically represents autochthonous organic matter. It dominates the terpane $\mathrm{m} / \mathrm{z}$ trace of sediment sample 2 from the eastern shelf, whereas the pseudohomologous series of the mature $17 \alpha, 21 \beta$-hopanes $\left(\mathrm{C}_{27}[\mathrm{Ts}, \mathrm{Tm}], \mathrm{C}_{29}{ }^{-}\right.$ $\left.\mathrm{C}_{35}\right)$ are barely visible (Figure $\left.2 \mathrm{f}\right)$. Extended $\left(>\mathrm{C}_{30}\right)$ hop$17(21)$-enes and $17 \beta, 21 \beta$-hopanes are diagenesis products of bacteriohopanetetrol (Table 1) and structurally closely related compounds are biosynthetic products of anerobic bacteria, whereas the lower members of the pseudohomologous series may also derive from diploptene and diplopterol (e.g., Gaines et al., 2008, and references therein). They occur to various extents in the surface sediments (e.g., sediment samples 2, 4 and 5; Figures 2c,e,f).

All of these compounds are indicators of (allochthonous) immature organic matter that commonly occurs a few tens or hundreds of meters deep but rarely in marine surface sediments (e.g., Cornford et al., 1979; Rullkötter et al., 1984). Thus, the most likely origin for these biomarkers in the surface sediments are drill cuttings recovered during penetration of organicmatter-rich Tertiary to Cretaceous deposits having immature to marginally mature organic matter. Until recently, when international regulations banned this practice, these cuttings were discarded into the sea (PEMEX, 2006, and personal communication, 2007). It is unusual that drill cutting material can be so unequivocally recognized by their biomarker pattern to be spread over an extended area of shallow sea bottom. In other cases, like in the North Sea, either dissipation by bottom currents is so effective that the traces of the cuttings material is 



Retention time $(\mathrm{min})$

Fig. 2. GC-MS terpane $(\mathrm{m} / \mathrm{z}, 191)$ and sterane $(\mathrm{m} / \mathrm{z}, 217+218)$ mass fragmentograms of the non-aromatic (saturated plus olefinic) hydrocarbon fractions of (a) a Jurassic oil (Gulf of Mexico), (b) a drill cuttings sample from the Chilam-1 well (Fig. 1), and (c-f) selected surface sediments. For symbol identification $c f$. graphs (a) and (f); Ts = 22,29,30-trinor-18 $\alpha$-neohopane, Tm = 22,29,30-trinor-17 $\alpha$-hopane.

lost (Central Graben area) or the bottom currents are so weak that the cuttings remain in close vicinity to the drilling location (Viking Graben area; J. Rullkötter, unpublished information).

A particularly interesting allochthonous compound not related to local petroleum is oleanane occurring as a
C-18 $\alpha / 18 \beta$ epimer mixture (Riva et al., 1988) or as virtually pure $18 \alpha$-oleanane. Oleanane derives from $\beta$-amyrin and other land-plant triterpenoids (Table 1) through a sequence of diagenetic reactions involving defunctionalisation of the precursor molecules and skeletal rearrangement of the 
Table 2. Saturated hydrocarbon biomarker maturity data for surface sediments, asphaltic sediments, cuttings samples, an asphalt and a crude oil from the Campeche Sound area.



a) Carbon Preference Index (carbon number range)

b) $20 S /(20 S+20 R)$ epimer ratio of $\mathrm{C}_{29} 5 \alpha, 14, \alpha, 17 \alpha$-steranes

c) $\alpha \beta \beta /(\alpha \alpha \alpha+\alpha \beta \beta)$ epimer ratio of $\mathrm{C}_{29} 5 \alpha, 14, \beta, 17 \beta$ - and $5 \alpha, 14, \alpha, 17 \alpha$-steranes d) $17 \alpha, 21 \beta$-hopane $/(17 \alpha, 21 \beta$-hopane+moretane $)$ epimer ratio e) $22 \mathrm{~S} /(22 \mathrm{~S}+22 \mathrm{R})$ epimer ratio of $\mathrm{C}_{32}$ dihomo-17 $\alpha, 21 \beta$-hopanes n.d. $=$ not determined due to interference of $n$-alkanes with other components. pentacyclic ring system (Rullkötter et al., 1994). Land-plant triterpenoids are biomarkers of angiosperms and restricted to fossil organic matter in Cretaceous and younger geological materials (Moldowan et al., 1994). On the Campeche shelf, oleanane, thus, cannot be related to the local crude oils ( $c f$. absence of oleanane in oil and asphalts; Figures 2 a,d). The terpane $(\mathrm{m} / \mathrm{z} 191)$ traces of sediment samples 4 and 5 (Figures $2 \mathrm{c}, \mathrm{e})$ show the presence of oleanane, although in strongly different amounts, and in sample 4 (Figure 2e) the less stable, later eluting $18 \beta$-epimer clearly dominates the more stable $18 \alpha$-epimer. Mature sediments and crude oils, if influenced by higher land plant material and geologically sufficiently young, only contain the thermally stable $18 \alpha$-oleanane (Riva et al., 1988).

Supporting evidence for the presence of cuttings in the surface sediments comes from the analysis of stored cuttings samples from different exploration or production wells. An example from the Chilam-1 well (Figure 1) is shown in Figure $2 \mathrm{~b}$. In the $\mathrm{m} / z 191$ mass fragmentogram $17 \beta, 21 \beta$-hopanes are still present, and in the extended $17 \alpha, 12 \beta$-hopanes series the $22 S / 22 R$ ratio has not reached the endpoint value of 0.60 ( $c f$. Peters et al., 2005), both indicating low to marginal maturity of the organic matter in the cuttings. The presence of oleanane (and other angiosperm-derived triterpenoids not identified in detail) is clear evidence that some of the hydrocarbons in the surface sediments originate from sedimentary rocks younger than the dominant Jurassic source rocks in the area. The complexity of the biomarker mixtures in the many of the surface sediments shows that cuttings containing organic matter with a wide range of thermal maturation were discarded and became mixed at the ocean floor.
Cuttings-derived biomarkers (e.g., oleanane) are widespread over the whole shelf area and very prominent in the vicinity of the offshore oil production zone in the southern part of the study area with its large number of production wells (encircled area in Figure 1). The occurrence of the same compounds further away from the centre of the drilling activity is in accordance with a seasonally changing current pattern in the Campeche Sound with a major down-coast current in fall and winter which meets an opposing along-shore current, generating seasonal offshore transport (Zavala-Hidalgo et al., 2003). Surface sediments in the northeast of the study area at a distance from the offshore petroleum exploration activities and very close to the coast in the South mainly contain autochthonous immature organic matter, often with diploptene dominating the $\mathrm{m} / \mathrm{z}$ 191 mass fragmentograms (e.g., Figure 2f). A characteristic lack of oleanane and a mature hopane distribution was found in the biomarker patterns of the Campeche Sound central shelf sediments (area inside and close to the broken circle line in Figure 1) encircled. This emphasizes the significant contamination with fossil Jurassic oil and its refinery products, but natural asphalt seepage may contribute to the load of petroleum hydrocarbons in this area as well.

\section{Conclusions}

Biological marker organic geochemistry is a powerful tool not only in petroleum exploration, but also in environmental studies as is demonstrated in a case study on the continental shelf of the Campeche Sound and a section of the adjacent slope and abyssal plain with natural asphalt occurrences. Besides natural and anthropogenic oil spills, drill cuttings 
a
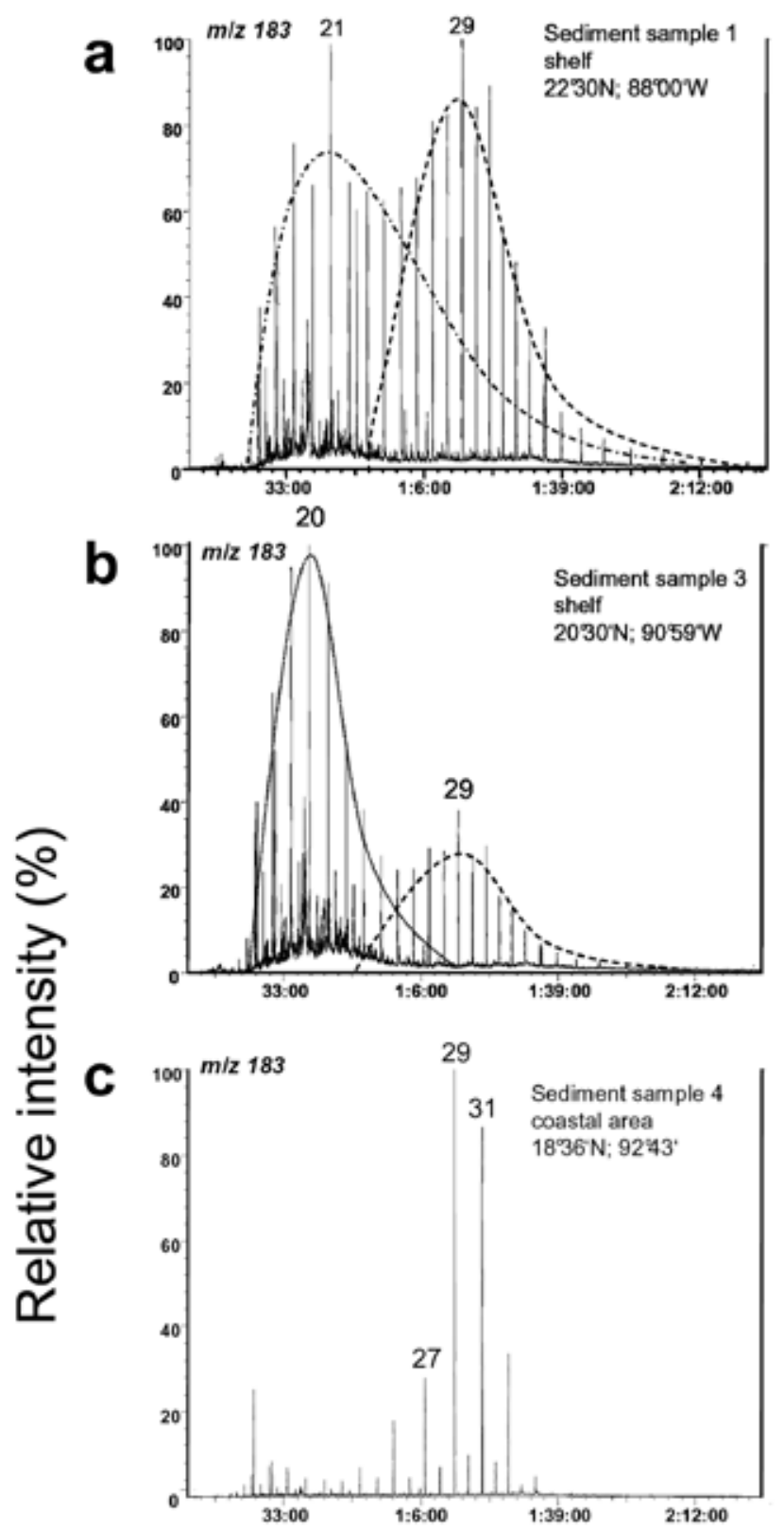

d

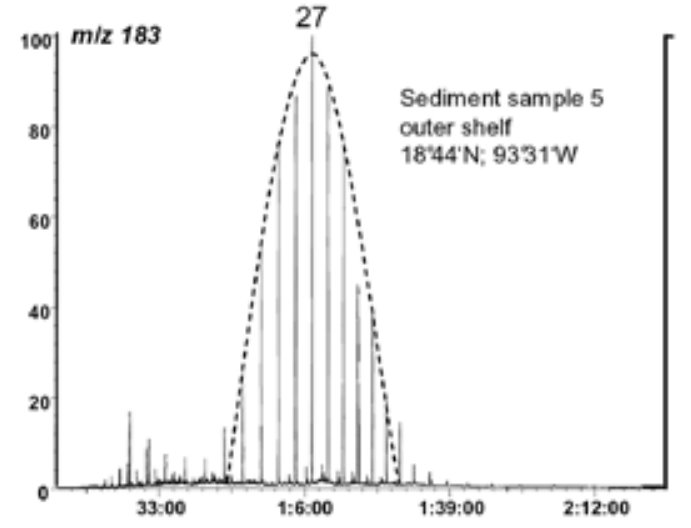

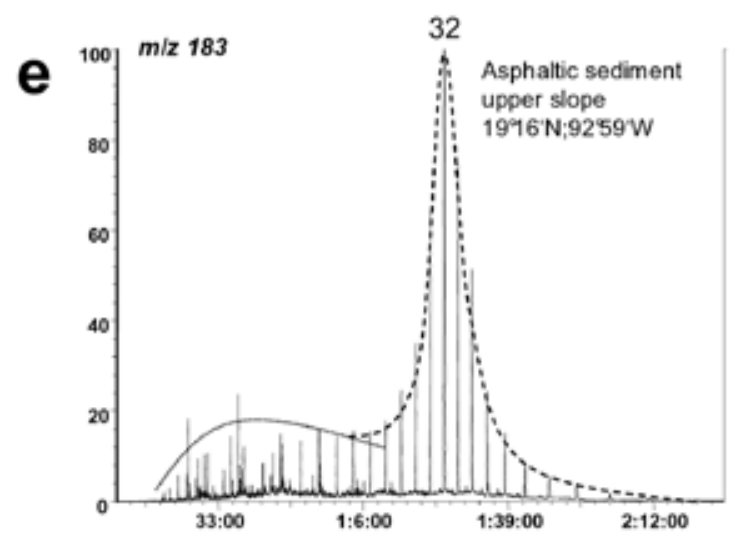

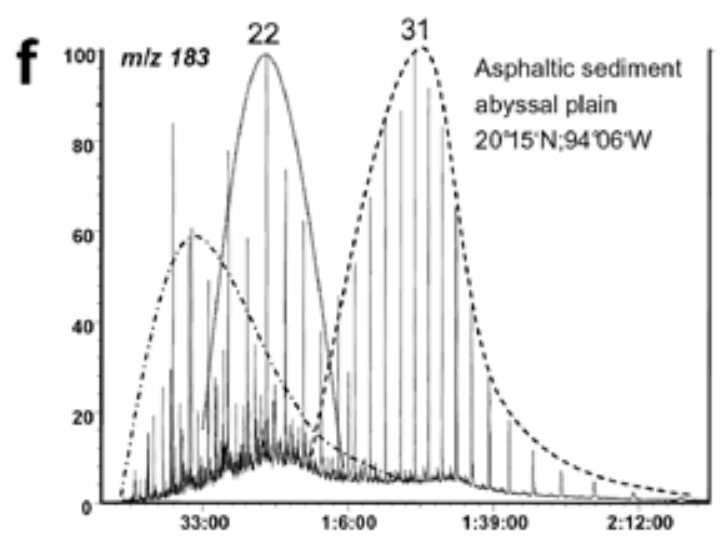

g

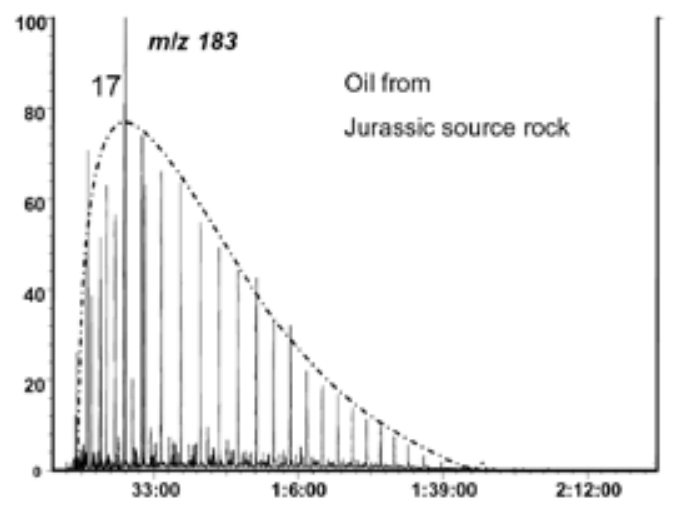

h

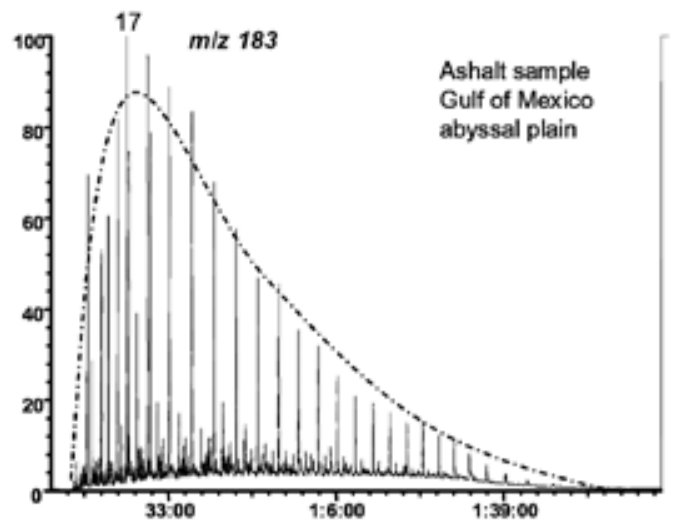

\section{Retention time ( $\min )$}

Fig. 3. GC-MS $n$-alkane ( $m / z$ 183) mass fragmentograms representing the $n$-alkane distributions of selected surface sediments (a-d), two asphaltic sediments (e-f), a crude oil (g), and a pure asphalt (h). 
apparently are an additional major source of hydrocarbon contamination in surface sediments of the shallow areas of the Campeche Sound. Redistribution by currents carries the cuttings material away from the area of drilling activities leading to a large variation in the extent and compositional signature of hydrocarbon contamination in surface sediments. Asphalt seeping from the subsurface is obviously related to the crude oils produced in the Campeche Sound oil fields.

\section{Acknowledgements}

Asphalt samples from METEOR cruise 67/4 were kindly provided by Prof. Elva Escobar Briones, National Autonomous University of Mexico City (UNAM). We appreciate the supply of crude oil and cuttings samples by PEMEX (PEP Subgerencia de Exploración; GSIPAC-RMSO) and technical support by Anke Müllenmeister (ICBM). The project was supported by the National Autonomous University of Mexico (UNAM, Project 132). We thank Dr. Sandra Ortega Lucach (Instituto Mexicano del Petróleo) and an anonymous referee for valuable comments in their reviews.

\section{References}

Angeles-Aquino, F. J., 1987, Estudio estratigráfico-sedimentológico del Jurásico Superior en la Sonda de Campeche: Ingeniería Petrolera AIPM, $28,45-55$.

Angeles-Aquino, F. J., 1994, Tectonic evolution, structural styles, and oil habitat in the Sonda de Campeche, Mexico: American Association of Petroleum Geologists Bulletin, 78, 1448-1449.

Bryant, W. R., Lugo, J., Cordova, C., Salvador, A., 1991, Chapter 2: Physiography and bathymetry, in: Salvador, A. (ed.), The Gulf of Mexico Basin: Geological Society of America, Boulder, CO, J, 13-30.

Cornford, C., Rullkötter, J., Welte, D., 1979, Organic geochemistry of DSDP Leg 47a, Site 397, eastern North Atlantic: Organic petrography and extractable hydrocarbons, in: von Rad, U., Ryan, W.B.F. et al. (eds.), Initial Reports of the Deep Sea Drilling Project: U.S. Government Printing Office, Washington, 47, part 1, 511-522.

Gaines, S., Eglinton, G., Rullkötter, J., 2008, Echoes of Life - What Fossil Molecules Reveal About Earth History: Oxford University Press, New York.

García-Cuellar, J. A., Arreguín-Sánchez, F., Hernández-Vázquez, S., LluchCota, D. B., 2004, Impacto ecológico de la industria petrolera en la Sonda de Campeche, México, tras tres décadas de actividad: Una revisión: Interciencia, 29, 311-319.

Guzmán-Vega, M. A., Mello, M. R., 1999, Origin of oil in the Sureste Basin, México: American Association of Petroleum Geologists Bulletin, 83, 1068-1095.

Guzmán-Vega, M. A., Ortíz, L. C., Román-Ramos, J. R., Medrano-Morales, L., Valdéz, L. C., Vázquez-Covarrubias, E., Ziga-Rodríguez, G., 2001, Classification and origin of petroleum in the Mexican Gulf Coast Basin: an overview, in Bartolini, C., Buffler, R. T., Cantú-Chapa, A. (eds.), The Western Gulf of México Basin: Tectonics, Sedimentary Basins, and Petroleum Systems: American Association of Petroleum geologists, Tulsa (OK): AAPG Memoir, 75, 127-142.

Holguín, Q. N., 1987, Evaluación geoquímica del sureste de México: Bolletín de la Asociatión Mexicana de Geólogos Petroleros, 37, 3-48.

MacDonald, I. R., Bohrmann, G., Escobar, E., Abegg, F., Blanchon, B., Blinova, V., Brückmann, W., Drews, M., Eisenhauer, A., Han, X., Heeschen, K., Meier, F., Mortera, C., Naehr, T., Orcutt, B., Bernard, B., Brooks, J., de Faragó, M., 2004, Asphalt volcanism and chemosynthetic life in the Campeche Knolls, Gulf of Mexico: Science, 304, 999-1002.

Macgregor, D. S., 1993, Relationships between seepage, tectonics and subsurface petroleum reserves: Marine Petroleum Geology, 10, 606-619.

Mackenzie, A. S., Patience, R. L., Maxwell, J. R., Vandenbroucke, M., Durand, B., 1980, Molecular parameters of maturation in the Toarcian shales, Paris
Basin, France-I. Changes in the configuration of acyclic isoprenoid alkanes, steranes and triterpanes: Geochimica et Cosmochimica Acta, 44, 1709-1721.

Mackenzie, A. S., Lewis, A. C., Maxwell, J. R., 1981, Molecular parameters of maturation in the Toarcian shales, Paris Basin, France - IV. Laboratory thermal alteration studies: Geochimica et Cosmochimica Acta, 45, 23692376.

Moldowan, J. M., Dahl, J., Huizinga, B. J., Fago, F. J., Hickey, L. J., Peakman, T. M., Taylor, D. W., 1994, The molecular fossil record of oleanane and its relationship to angiosperms: Science, 265, 768-771.

Pemex Exploración y Producción, 2006, Hydrocarbon Reserves of Mexico, Evaluation as of January 1. 2006: PEMEX, México, 128 pp.

Peters, K. E., Walters, C. C., Moldowan, J. M., 2005, The Biomarker Guide, $2^{\text {nd }}$ edition: Cambridge University Press, New York.

Radke, M., Willsch, H., Welte, D. H., 1980, Preparative hydrocarbon group type determination by automated medium liquid chromatography: Analytical Chemistry, 52, 406-411.

Riva, A., Caccialanza, P. G., Quagliaroli, F., 1988, Recognition of $18 \beta(\mathrm{H})$ oleanane in several crudes and Tertiary-Upper Cretaceous sediments. Definition ofanewmaturity parameter: Organic Geochemistry, 13, 671-675.

Rullkötter, J., 2001, Geochemistry, Organic, in: Meyers, R.A. (ed.), Encyclopedia of Physical Science and Technology, $3^{\text {rd }}$ edition: Academic Press, San Diego, 6, 549-574.

Rullkötter, J., 2006, Organic Matter: The driving force for early diagenesis. In: Schulz, H.D., Zabel M. (eds.), Marine Geochemistry, $2^{\text {nd }}$ Edition: Springer, Heidelberg, 125-168.

Rullkötter, J., Mukhopadhyay P. K., Schaefer R. G., Welte D. H., 1984, Geochemistry and petrography of organic matter in sediments from Deep Sea Drilling Project Sites 545 and 547, Mazagan Escarpment, in: Hinz, K., Winterer, E. L. et al. (eds.), Initial Reports of the Deep Sea Drilling Project: U.S. Government Printing Office, Washington, 79, 775-806.

Rullkötter, J., Peakman, T. M., ten Haven, H. L., 1994. Early diagenesis of terrigenous triterpenoids and its implications for petroleum geochemistry. Organic Geochemistry, 21, 215-233.

Scholz-Böttcher, B. M., Ahlf, S., Vázquez-Gutiérrez, F., Rullkötter, J., 2008. Sources of hydrocarbon pollution in surface sediments of the Campeche Sound, Gulf of Mexico, revealed by biomarker analysis: Organic Geochemistry, 39, 1104-1108.

Seifert, W. K., Moldowan, J. M., 1980, The effect of thermal stress on sourcerock quality as measured by hopane stereochemistry, in: Douglas, A.G., Maxwell, J.R. (eds.), Advances in Organic Geochemistry 1979: Pergamon Press (Oxford), 229-237.

Seifert, W.K., Moldowan, J. M., Jones, R. W., 1980, The application of biological markers to petroleum exploration: Proceedings of the Tenth World Petroleum Congress, 2, 425-440.

Soto-Cuervo, A., Ortega-González, V., Mora-Oropeza, G., 2004, Present and future of the Salina del Istmo basin and its offshore extension into the Gulf of Mexico, AAPG International Conference: October 2427, Cancun, Mexico: American Association of Petroleum Geologists, extended abstract no. A91518.

Taylor, D. W., Li, H., Dahl, J., Fago, F. J., Zinniker, D., Moldowan J. M., 2006, Biogeochemical evidence for the presence of the angiosperm molecular fossil oleanane in Paleozoic and Mesozoic non-angiospermous fossils: Paleobiology, 32, 179-190.

Vázquez, G. F., Virender, K. S., 2004, Major and trace elements in sediments of the Campeche Sound, southeast Gulf of Mexico: Marine Pollution Bulletin, 48, 87-90.

Zavala-Hidalgo, J., Morey, S. L., O’Brien, J. J., 2003, Seasonal circulation on the western shelf of the Gulf of Mexico using a high-resolution numerical model: Journal of Geophysical Research, 108 (C12), 3389.

Manuscript received: November 4, 2008

Corrected manuscript received: February 16, 2009

Manuscript accepted: February 20, 2009 